Lussier-Desrochers, D., Normand, C. L., Romero-Torres, A., Lachapelle, Y., Godin-Tremblay, V., Dupont, M.-È., Roux, J., Pépin-Beauchesne, L., \& Bilodeau, P. (2017). Bridging the digital divide for people with intellectual disability. Cyberpsychology: Journal of Psychosocial Research on Cyberspace, 11(1), article 1. doi: 10.5817/CP2017-1-1

\title{
Bridging the digital divide for people with intellectual disability
}

\author{
Dany Lussier-Desrochers ${ }^{1}$, Claude L. Normand ${ }^{2}$, Alejandro Romero-Torres ${ }^{3}$, Yves Lachapelle ${ }^{1}$, Valérie Godin- \\ Tremblay ${ }^{1}$, Marie-Ève Dupont ${ }^{1}$, Jeannie Roux ${ }^{4}$, Laurence Pépin-Beauchesne ${ }^{1}$, \& Pascale Bilodeau ${ }^{1}$ \\ ${ }^{1}$ Université du Québec à Trois-Rivières, Trois-Rivières, Québec, Canada \\ ${ }^{2}$ Université du Québec en Outaouais, Gatineau, Québec, Canada \\ ${ }^{3}$ Université du Québec à Montréal, Montréal, Québec, Canada \\ ${ }^{4}$ Institut universitaire en DI et TSA, Trois-Rivières, Québec, Canada
}

\begin{abstract}
Recent data from several studies and surveys confirm that our society has entered the digital and information age. Some authors mention that information and communication technologies (ICT) have the potential to enhance people's power to act and promote equal citizen participation. These elements are particularly important for people living with intellectual disability (ID). However, it seems that the use of ICT is challenging for these people and that a digital divide has gradually formed between them and the connected citizen. The general objective of this theoretical article is to identify and illustrate the dimensions that must be taken into account to promote the digital participation of people with ID. The model is based on a qualitative analysis of scientific publications using a conceptual-style matrix (Miles \& Huberman, 2003). The coding categories were derived from two main sources: the accessibility pyramid and the Human Development Model - Disability Creation Process. Five challenges or conditions associated with digital inclusion were identified: access to digital devices, sensorimotor, cognitive and technical requierements and the comprehension of codes and conventions. For each one, the obstacles and facilitators identified in the literature are described. These reflections and principles led us to propose a model in the shape of a gear. The proper operation of the gear system depends on the fit between individual resources and environmental support. The model is a first step to understand the digital inclusion of people with ID.
\end{abstract}

Keywords: intellectual disability; information and communication technologies; Internet; digital divide

\section{Introduction}

Recent data from several studies and surveys confirm that our society has entered the digital and information age (Licoppe, 2009). By definition, the digital society is one where information and communication technologies (ICT) are the cornerstone of interactions between individuals (Compiègne, 2011). For citizens, this shift has several advantages, including almost unlimited access to information and entertainment as well as a proliferation of opportunities to socialize through digital media. Some authors mention that ICT have the potential to enhance people's power to act and promote equal citizen participation (Allard, 2007; Jenkins, 2006). These elements are particularly important for people living with intellectual disability (ID) (Lachapelle \& Wehmeyer, 2003; Watkins, 2014). However, it seems that a gap has gradually emerged between them and the connected citizen (Chadwick, Wesson, \& Fullwood, 2013). This could be explained in part by the perceived risks 
of Internet access and use (Chadwick, Quinn, \& Fullwood, 2016; Seale, 2014) as well as evidence of online victimization (Buijs, Boot, Shugar, Fung, \& Bassett, 2016; Sallafranque St-Louis, 2015) for people with ID.

The article is a theoretical essay based on a literature review. It identifies the dimensions associated with the digital inclusion of people with ID. The first part presents the use of ICT by people with ID, as well as the benefits identified. Then it describes the phenomenon of digital exclusion (also known as digital divide or digital gap) observed among these people. The research method used to identify the dimensions is then presented. The results section describes each of the dimensions associated with the digital inclusion of these people and the dynamics underlying their relationships. The last part presents our conclusions, a discussion about the model as well as some perspectives for future development.

\section{Intellectual Disability}

In the 11th edition of its Definition and Classification Manual, the American Association on Intellectual and Developmental Disabilities (AAIDD, 2010) defines intellectual disability as a condition "characterized by significant impairments both in intellectual functioning and in adaptive behavior as expressed in conceptual, social, and practical adaptive skills" (p.1), that is present before the age of 18 years. The literature mentions that the prevalence of this condition varies from $1 \%$ to $3 \%$ in the general population (Tassé \& Morin, 2003). Nonetheless, the simple presence of these three criteria should not justify a diagnosis of ID; it is also important to consider five postulates that take into account the great complexity of a multidimensional assessment including sensorimotor, behavioural and communication differences as well as the co-existence of limits and strengths within an individual (AAIDD, 2010). The AAIDD has further established that intellectual disability no longer stems only from the person, but also from the person's interactions with his or her environments. Given this conceptualization, it becomes obvious that specific means must be implemented to adapt the environment to these people's individual abilities so they can express and improve them or develop new ones, as well as participate and exercise a valued role in society and have a better quality of life (AAIDD, 2010).

Lachapelle and Wehmeyer (2003) mention that exercising this role and promoting quality of life entails the power to act and the self-determination of people with ID. Indeed, for these people, the concept of social participation underlies the complete realization of a lifestyle that includes, notably, everyday activities and social roles (Fougeyrollas, Cloutier, Bergeron, Côté, \& St-Michel, 1998). Furthermore, some models suggest that the disability situation and social participation are at opposite ends of a same continuum where the positioning depends on the interaction between personal and environmental factors (Fougeyrollas et al., 1998). In sum, an increase in the power to act goes hand in hand with the notion of self-determination and social participation (Lachapelle \& Wehmeyer, 2003). Moreover, this notion of social participation is a central component of various reference frameworks and government policies in several countries (AAIDD, 2016; Fédération québécoise des Centres de Réadaptation en Déficience intellectuelle [FQCRDITED], 2013; Office des personnes handicapées du Québec [OPHQ], 2009; United Nations, 2006; World Health Organization [WHO], 2010).

Recently, this notion of social participation was enhanced by a new component: social participation through ICT, or digital participation (Lussier-Desrochers, Normand et al., 2016). This new area of interest is based on two main elements: on the one hand, results from studies showing the benefits associated with the use of technologies by people with ID (Lachapelle, Lussier-Desrochers, \& Pigot, 2007; Lachapelle \& Therrien-Bélec, 2013; Näslund \& Gardelli, 2013; Seale, 2014) and, on the other hand, the literature showing the presence of a digital divide limiting access of people with ID to these technologies (Chadwick et al., 2013; Hoppestad, 2013). These elements are presented in turn in the upcoming subsections.

\section{Benefits Associated With the Use of Technologies by People With ID}

In recent years, several adapted software programs, applications and interfaces have been created to meet the needs of people with ID and to promote their self-determination and social participation (Ayres, Mechling, \& Sansosti, 2013; Davies et al., 2015). This interest stems notably from the results of studies showing that the use of ICT by these people has certain benefits, such as communication; social interaction and interactions within the community (Reichenberg, 2016), like making purchases at the grocery store or restaurant (Allen, Vatland, Bowen, \& Burke, 2015; Burckley, Tincani, \& Guld Fisher, 2015); travelling around the community (Ayres et al., 
2013; Mechling \& Seid, 2011); and performing tasks in residential areas (Lachapelle, Lussier-Desrochers, Caouette, \& Therrien-Bélec, 2011; Taber-Doughty, Shurr, Brewer, \& Kubik, 2010). In sum, technology helps to raise the level of autonomy in performing daily activities as well as learning new skills (Davies, Stock, \& Wehmeyer, 2002; Sigafoos et al., 2005; Wu, Cannella-Malone, Wheaton, \& Tullis, 2016). It is important, however, to point out that the majority of studies show that there is great variability among individuals and that their needs must be analyzed accurately (Lussier-Desrochers, Caouette, \& Godin-Tremblay, 2015; Lussier-Desrochers et al., 2014).

People with ID are currently using several types of technological solutions, including tablets (Allen et al., 2015; Burckley et al., 2015), smartphones (Lachapelle et al., 2011), portable digital players like the iPod Touch (Wu et al., 2016) or other similar devices (Mechling \& Seid, 2011), desktop and laptop computers (Davies et al., 2002; Sigafoos et al., 2005), as well as telehealth cameras (Taber-Doughty et al., 2010). Optimal use of many ICT require an Internet connection. This is the case notably for such mobile technologies as smartphones or tablets, which are of very limited use if not connected to the Internet. Therefore, a more detailed analysis of the Internet use patterns of these people is needed to clearly understand the issues involved in their use of ICT.

There is little data on this population's Internet use patterns (Hoppestad, 2013; Lussier-Desrochers, Dupont, Lachapelle, \& Leblanc, 2011; Normand, Rodier, Lussier-Desrochers, \& Giguère, submitted; Sallafranque St-Louis, 2015). Nonetheless, some authors from different countries (United States, Sweden, Canada, Israel) note that when these people use the Internet, they do so primarily for the purpose of communicating with other users, strangers or not, through social media (Löfgren-Mårtenson, Sorbring, \& Molin, 2015; Molin, Sorbring, \& LöfgrenMårtenson, 2015; Normand et al., submitted; Sallafranque St-Louis, 2015; Shpigelman \& Gill, 2014). Using this new form of social interaction allows them to define themselves "like everyone else" and to create a sense of belonging to a "normal" community (Löfgren-Mårtenson et al., 2015; Shpigelman, 2016). Video or picture entertainment is also very popular (Sallafranque St-Louis, 2015). However, online browsing or communication that requires a great deal of reading or writing poses problems (Harrysson, Svensk, \& Johansson, 2004; McClimens \& Gordon, 2009; Molin et al., 2015; Shpigelman \& Gill, 2014; Wong, Chan, Li-Tsang, \& Lam, 2009). And although, compared with the rest of the population, fewer of these people use the Internet and spend less time on it (Parsons, Daniels, Porter, \& Robertson, 2008; Wells \& Mitchell, 2014), they seem to be more at risk of online sexual victimization or extortion (Löfgren-Mårtenson et al., 2015; Normand \& Sallafranque St-Louis, 2015, 2016; Wells \& Mitchell, 2014). Consequently, it is not unusual for the people around them to attempt to control or limit their access to the Internet (Chadwick et al., 2013; Löfgren-Mårtenson et al., 2015).

In summary, ICT appear to be a very promising avenue for supporting social participation of people with ID. Be that as it may, it seems that not all people with ID use technologies daily and that there are issues specifically related to their use by these people. This phenomenon of digital divide is currently a concern for several actors evolving in the field of ID.

\section{The Phenomenon of Digital Divide for the Population with ID}

Some authors mention that instead of an increase in social participation, the reverse is occurring: a widening gap between people with ID and the connected citizen (Attour \& Longhi, 2009; Batey \& Waine, 2015; Dagenais, Poirier, \& Quidot, 2012; Eveno, 1998). Moreover, the majority of people with ID are unable to take full advantage of the digital and information society (Carey, Friedman, \& Bryen, 2005; Palmer, Wehmeyer, Davies, \& Stock, 2012; Wehmeyer, Palmer, Smith, Davies, \& Stock, 2008). This gap translates more precisely into a feeling of exclusion called "digital divide" (Organisation for Economic Co-operation and Development [OECD], 2004; Vodoz, 2010). This situation goes against social and government policies underscoring the importance of ensuring these people's full and complete participation in all areas of social life, which include employment, schooling and recreation (OPHQ, 2009). Therefore, a number of people with ID can neither contribute to, nor benefit from, the digital society, because their access is obstructed by several elements. This is due notably to the fact that the digital environment in which they must interact is common to all citizens and thus not adapted to their abilities and needs for support (Dagenais et al., 2012; Rocha et al., 2012).

Several authorities have rallied to identify measures for supporting the digital inclusion of these people (Coleman Institute for Cognitive Disabilities, 2013; President's Committee for People with Intellectual Disabilities 
[PCPID], 2015). According to Compiègne (2011), this is the type of reflection that should be given priority. In Canada, many social actors are preoccupied by this phenomenon and try to find solutions to resolve this issue. For example, in the province of Quebec, a Charter for digital inclusion of people with ID was launched in 2016; it presents 10 actions that must be prioritized in order to reduce the gap between people with ID and the connected citizens (\#CTI, 2016). This action is consistent with similar initiatives in other countries (e.g. The Rights of People with Cognitive Disabilities to Technology and Information Access produced in the United States).

\section{Objectives of the Theoretical Essay and Method Used to Identify the Dimensions of Digital Inclusion}

Objective of the theoretical essay. The general objective of this theoretical essay is to identify the dimensions associated with the digital inclusion of people with ID. This identification will make it possible to propose an integrative model of the dynamics underlying the relationship between these dimensions.

\section{Method}

A two-phase process was used to identify the dimensions associated with digital inclusion. First, a search of peer-reviewed articles was performed via the PsycINFO and ERIC databases. The first phase of the review aimed to draw an accurate picture of technology use by people with ID. To do so, keywords relating to the three following concepts were used: (a) intellectual disability; (b) Internet and technologies and (c) usage (Table 1). This first search resulted in 303 articles. The article abstracts were read to see if they met the inclusion criteria (present an experience with ICT usage by people with ID and be published in French or in English). For this phase, a total of 161 scientific articles were retained (Table 2).

This first review was combined with a second one, which aimed, this time, at better defining the phenomenon of digital exclusion experienced by people with ID. The concept of exclusion was added to the initial concepts in the literature search conducted in PsycINFO and ERIC. From this second search, 20 articles were retained, on a total of 39 found. Finally, a complementary Google search was performed to document dimensions that may not have been identified in the scientific literature. However, in an effort to simplify the process, this complementary component included initiatives offered in Québec only. This focus allowed the authors to produce a model close to their social reality.

Further to this first literature search, the contents of the documents retained were analyzed qualitatively using a conceptual-type matrix to organize the information coherently (Miles \& Huberman, 2003) (Table 3). The coding supra-categories and sub-categories used were derived from two main sources: the accessibility pyramid (Lussier-Desrochers, Normand et al., 2016) and the Quebec Classification: Disability Creation Process (QC:DCP) (Fougeyrollas et al., 1998). The accessibility pyramid is a conceptual model created by the authors in order to understand digital inclusion of people with ID and autism spectrum disorder. It comprises five dimensions (see Table 3), and was created to support front-line workers in the implementation of technologies in clinical settings. Another theoretical framework used in our analyses is the Quebec Classification: Disability Creation Process (Fougeyrollas et al., 1998). It states that handicapping situation, on the one hand, and social participation, on the other, result from an interaction between environmental and personal factors throughout a lifetime. Facilitators and obstacles are present in both the personal and the environmental conditions in which a person engages in daily activities and social roles (life habits).

The sections below present the results of the analysis according to the dimensions of the matrix. 


\section{(a) intellectual disability}

Multiple Disabilities

Delay Development

\section{(b) Internet and technologies}

Cellular Phone*

Text Messag*

Blog*

Internet

Microcomputer*

Electronic Communication

Mobile Device*

Augmentative Communication

Assistive Technolog*

Information Technology

Technolog*

\section{(c) usage}

Activities of Daily Living

Food

Household Management

Food Preparation

Communication

Socialization

Interpersonal Relationships

Family Relations

Social Interaction

Social Dating

Interpersonal Interaction

Friendship

Cyberbullying

Cybersex

Daily Activities

Hobbies

Games

Computer Games

Recreation

Help Seeking Behavior

Safety

Transportation

Wayfinding

\section{d) exclusion}

Computer Literacy

Information Literacy

Digital Divide

Social Deprivation

Disadvantaged

Deprivation

Accommodation (Disabilities)

Marginalization
Intellectual* Development* Disorder*

Down's Syndrome

Online Community

Social Media

Computer Application*

Computer* Mediated Communication

Computer Peripheral Device*

Websites

Social Network*

Online Social Network*

Computer Software

Computer*
Spatial Orientation (Perception)

Finance

Shopping

Internet Addiction

Internet Usage

Interpersonal Communication

Hygiene

Self-Care Skills

Clothing

Health

Physical Health

Mental Health

Learning

Computer Simulation

Computer Searching

Education

Employee Skills

Task

Job Performance

Electronic Commerce

Electronic Communication

Electronic Learning

Access to Information*

Technological Literacy

Barrier*

Problem*

Access to Computer*

Autoinstructional Aid*

Appropriate Technology 
Table 2. Articles Retrieved and Excluded From the Databases.

\begin{tabular}{lccc}
\hline & N retrieved & N excluded & N retained \\
\hline PsycINFO & 101 & 41 & 60 \\
ERIC & 202 & 87 & 115 \\
Total & $\mathbf{3 0 3}$ & $\mathbf{1 2 8}$ & $\mathbf{1 7 5}$ \\
Duplicates & & & 14 \\
\hline N of article analyzed & & & $\mathbf{1 6 1}$ \\
\hline
\end{tabular}

Table 3. Conceptual Matrix Created For the Qualitative Analysis.

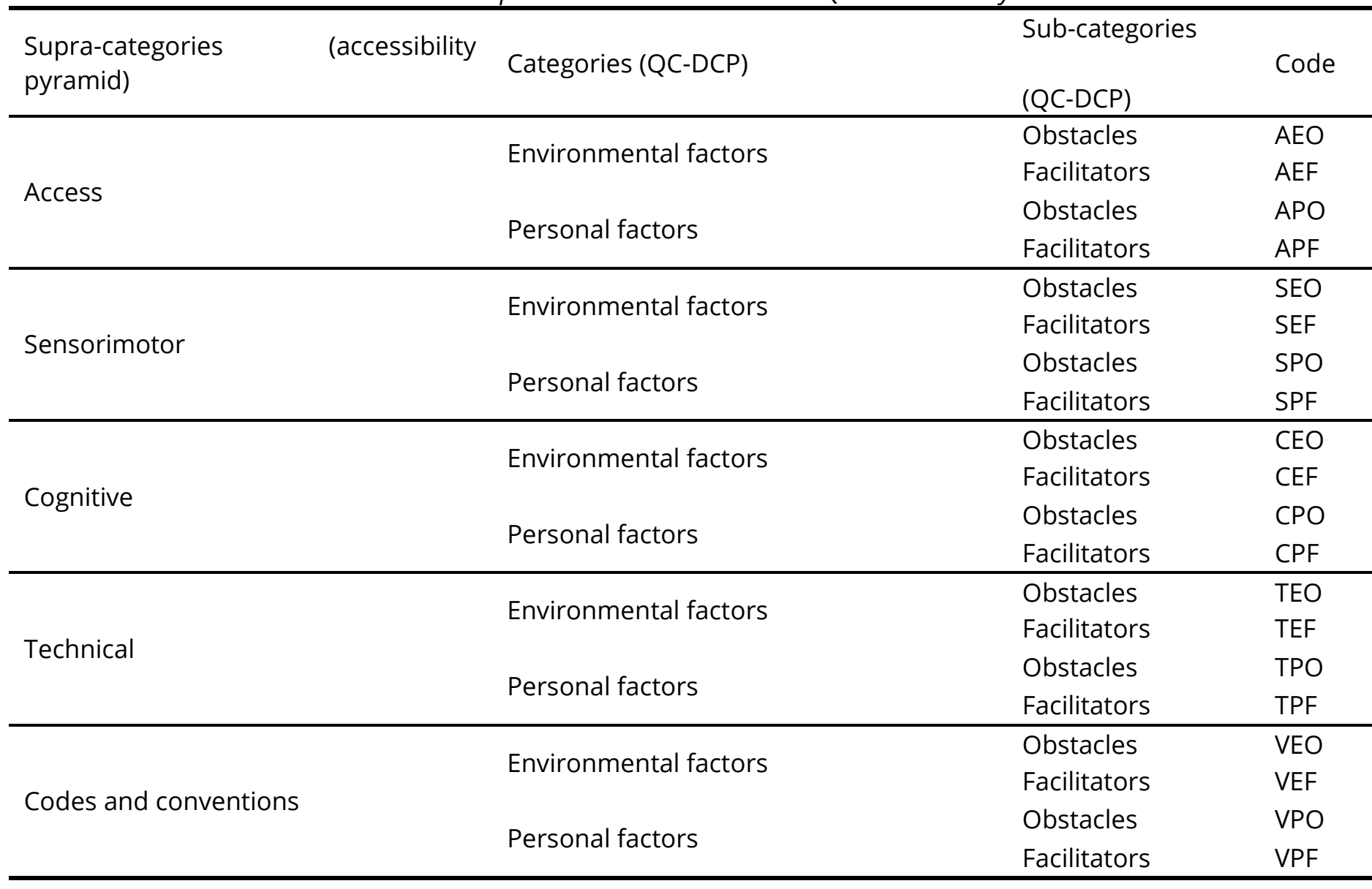

\section{Results}

\section{Dimensions Associated with the Digital Inclusion of People With ID}

Five digital access dimensions or conditions were identified. This section presents the information relating to the dimensions found in the literature (internet access, sensorimotor, cognitive, technical, social conventions). For each one, the obstacles and facilitators identified in the literature are presented for the personal and the environmental factors.

Dimension relating to devices and Internet access. One of the digital inclusion dimensions is, of course, access to technological devices by people with ID. To access the Internet, its content and digital services, people must necessarily go through technological devices (computer, digital tablet, smartphone, router) that are connected to this network. The literature analysis shows two main ways that people with ID can access these devices: (a) personal ownership of the technology through a purchase, a technology-access program or a 
donation; or (b) an equipment loan from a friend or family member, from an organization or through an equipment-lending program.

For the first option, people's financial resources are a major barrier. In fact, the Institut de la statistique du Québec (2013) advances that participating in the digital society requires a certain financial investment for the purchase of equipment (computer, smartphone, digital tablet, router). Furthermore, there are costs involved in connecting to the Internet. That said, low income is a major risk factor inherent to the population with ID. Indeed, provincial and national data show that these people's living environment is often affected by poverty (Canadian Association for Community Living, 2013; OPHQ, 2013). It is thus clear that access to technologies is compromised by their financial resources. Moreover, the analysis shows that additional costs are often involved in obtaining technological devices adapted to the person's specific needs (e.g., purchase of adapted peripherals or specialized applications).

Concerning this first element, the environment might provide support and compensation. Indeed, the purchase option is not the only possibility. The review shows that access programs offered by such organizations as the government or private foundations enable some people to acquire their own device. However, several of the initiatives identified make the hardware available but do not cover the cost of owning the technologies (Internet connection, purchase of applications or specialized peripherals, carrying case, etc.). In this regard, the total cost of owning a digital tablet (including direct and indirect costs, such as network connection, security software or maintenance) is often twice the initial cost of the tablet itself (Morphy, 2010; Principled Technologies, 2013). Therefore, although people may have a technological device donated to them, it is very probable that they will not have the financial means to pay the additional usage costs. Moreover, Dagenais et al. (2012) specifies that the equipment given to these people is often obsolete and prone to technical problems, which could lead to their underusing, if not completely giving up on, the technology.

Therefore, the second option appears more promising. First, there is the possibility of a short-term loan, like a digital tablet borrowed from a municipal library (e.g., Ville de Trois-Rivières, 2015). However, this method of borrowing remains complex for people who have difficulties travelling. It also carries a number of risks related to divulging personal information. Motor problems put the device at risk of being dropped, and the absence of adapted peripherals make regular loans less appealing. In Québec, some government agencies have also created equipment-lending programs (Association québécoise des troubles d'apprentissage [AQETA], 2016; OPHQ, 2011; Projet ministériel d'aide technique à la communication [PMATCOM], 2015), but a survey revealed that they do not seem to adequately meet all the needs of these people (Lussier-Desrochers, Caouette, \& GodinTremblay, 2016), nor do they include Internet access or cover indirect usage costs. Therefore, a last option for these people is seemingly to share a device with friends or family members (e.g., family computer), which can significantly reduce the number of hours of use. In short, the dimension relating to physical access to adapted devices constitutes an obstacle to the digital inclusion of people with ID, adding to the challenges of connecting to the Internet. Finally, despite the importance of this element, there is little documentation on the subject in the scientific literature, compared with the other dimensions presented below. This situation was previously noted by Chadwick et al (2013) and by Palmer et al. (2012).

Sensorimotor dimension. A second dimension of accessibility concerns the user's sensorimotor skills in relation to ICT handling demands. In fact, several studies show that the use of technological devices requires a certain minimum of sensorial (mainly tactile, visual, auditory and proprioceptive) and motor (fine and gross motor) abilities (Dagenais et al., 2012).

Therefore, with respect to person-related risk factors, the co-occurrence of ID and of sensorimotor limits is scientifically documented (Cleaver, Ouellette-Kuntz, \& Hunter, 2009; Chadwick et al., 2013 ; Crow, 2008; Dagenais et al., 2012; Michel, Masson, \& Sperandio, 2006; Wong et al., 2009). They represent a major obstacle to using the Internet notably because they have direct repercussions on the performance of basic actions required to operate the technological devices that connect to this network. For example, a lack of upper-limb coordination, prehension or dexterity can make it difficult to use a keyboard or a mouse (Cleaver et al., 2009; Dagenais et al., 2012; Wong et al., 2009). Additionally, motor constraints often limit reaction time and execution speed, making certain activities difficult to perform because of time restrictions, when filling out a form or shopping online, for 
example (Carmeli, Bar-Yossef, Ariav, Levy, \& Liebermann, 2008; Dagenais et al., 2012). Furthermore, people with ID may also have sensorial (visual, auditory) difficulties when browsing the Internet (Dagenais et al., 2012).

These difficulties in an individual also collide with environmental obstacles related to the ergonomics of the devices and the software, which can impede access to online content. For instance, the presence of little tabs on Internet sites or the small size of the devices (e.g., cellphones) make them complicated to handle for people with ID (Dagenais et al., 2012; Tanis et al., 2012). Moreover, a growing number of Internet sites use multimedia to transmit information, which represents a hindrance for people with visual and auditory limits (Michel et al., 2006). That said, nearly $80 \%$ to $90 \%$ of Internet sites would not be navigable by people with these types of difficulties (Michel et al., 2006).

The analysis of the studies found revealed that a number of environmental facilitators can compensate for the obstacles encountered. Among the solutions identified, the most interesting avenue appears to be the installation of technological devices adapted to the person's specific needs (Danial-Saad, Weiss, \& Schreuer, 2012; Grace, Raghavendra, Newman, Wood, \& Connell, 2014). Several peripherals are currently available on the market, including alternative mice (Danial-Saad et al., 2012), enlarged keyboards (Abilities expo, 2015), touch screens (Stephenson \& Limbrick, 2015), software for operating a computer by pupillary motion (Dube \& Wilkinson, 2014; Light \& Mcnaughton, 2014), as well as voice synthesis and recognition systems (Grace et al., 2014). The studies conducted thus far indicate that this type of peripheral helps improve Internet access for people with these sensorimotor limits (Raghavendra, Newman, Grace, \& Wood, 2013). However, given the heterogeneity of the people's sensorimotor profiles, the authors tend to favour a personalized approach to adapting devices (Cleaver et al., 2009; Crow, 2008).

Cognitive dimension. The cognitive requirements of the digital world represent another accessibility dimension. This dimension was previously adressed by Chadwick et al. (2013). Compiègne (2011) mentions that [Translation] "people's initial cognitive abilities remain determinant and discriminant" in ensuring the efficient use of digital technologies (including Internet access). To date, the studies' results suggest that interacting with technologies and digital content requires the mobilization of several cognitive components, like inductive reasoning, problem-solving skills, short- and long-term memory, reasoning, planning, reflection and deduction (Chevalier \& Tricot, 2008; Dagenais et al., 2012; Tanis et al., 2012; Tricot, 2007; Rivas-Costas et al., 2014). Reading and writing skills also influence Internet use (Michel et al., 2006; Rivas-Costas et al., 2014). Yet, the vast majority of these functions are posing a problem in people with ID, who thus have difficulty understanding how the devices work, as well as how to decipher the symbols, formulate a query in a search engine, select relevant content or even understand the information provided (Danielsson, Henry, Messer, \& Rönnberg, 2012; Harrysson et al., 2004). Furthermore, Williams and Nicholas (2006) noted that people with cognitive limitations do not use the mouse efficiently even if they have the necessary motor abilities. For instance, they click excessively, point to the screen instead of using the mouse, pull their hand back after each action with the mouse, and drag the cursor randomly across the screen. Moreover, they often react hastily and select the first option by default, which represents a major obstacle to browsing the Internet (Lussier-Desrochers et al., 2011; Williams \& Nicholas, 2006).

The studies' results show also that the digital environment makes it complicated to access information due to the quantity, variety and way it is fragmented (Bunning, Trapp, Seymour, Fowler, \& Rollett, 2010; Tricot, 2007). Nonetheless, this domain is only in its infancy and few studies have yet looked into the issue (Hoppestad, 2013). Meanwhile, Chen (2010) stresses that reading hypertext requires more cognitive efforts than reading text on paper. Additionally, Wong and colleagues (2009) show that the more steps involved in a technology, the greater the difficulties for people with cognitive limitations. In short, the basic actions involved in browsing the Internet solicit a vast set of cognitive skills (Harrysson et al., 2004; Lussier-Desrochers et al., 2011; Tanis et al., 2012; Wong et al., 2009). Finally, several authors say that using technologies is often complicated by confusing elements, such as only one button to turn a cellphone both on and off (Williams \& Nicholas, 2006).

To overcome cognitive limits, many solutions can be set up in a person's environment. However, no consensus emerged from the scientific literature regarding which ones to favour. First, adapted applications, Internet sites and web browsers have been developed in recent years to help reduce the cognitive load associated with the use of digital tools (Hall, Conboy-Hill, \& Taylor, 2011; Moisey \& van de Keere, 2007; Perkins \& LaMartin, 2012; 
Rocha et al., 2012; Stock, Davies, Davies, \& Wehmeyer, 2006; Williams \& Hennig, 2015; Wong et al., 2009). Other authors suggest instead to remedy some difficulties by configuring certain parameters through the control panel, for instance, modifying the mouse settings or enlarging the font (Rivas-Costas et al., 2014; Williams \& Nicholas, 2006). Finally, some believe that the solution would be to take into account universal accessibility rules, so that everyone in the community could access the same digital environment (Blanck, 2014; Harrysson et al., 2004; Karreman, van der Geest, \& Buursink, 2007; Tanis et al., 2012). Unfortunately, designers give very little consideration to these rules (Bunning, et al., 2010; Harrysson et al., 2004; Kennedy, Evans, \& Thomas, 2011; Tanis et al. 2012). That said, Brangier and colleagues (2010) believe that the main problem with these rules is that there are far too many (between 944 and 3000 rules). To overcome the problem, researchers (Hoppestad, 2013; Langevin, Rocque, Ngongang, \& Chalghoumi, 2012) recommend that the reference group for designing technological tools consist of people with ID, given their major cognitive difficulties.

Technical dimension. A fourth dimension emerged from the literature: technical skills. This one refers to the skills that technology and Internet users need to keep their devices in working order. So, to ensure the efficiency and sustainability of the computer equipment, preventing the risks that can jeopardize its proper functioning is essential. Some technologies, notably those connected to the Internet, often expose the user's computer equipment to potential risks. Indeed, if preventive measures are not taken (e.g., antivirus software), viruses, spyware, Trojan horses or other malware may temporarily or permanently damage the user's computer equipment and thus necessitate repairs or even replacement of some components (Newman, 2009). This situation is even more worrisome given the limited financial resources of people with ID. In the scientific literature, few studies deal specifically with the technical difficulties encountered by Internet users with ID. Yet, a study by Lussier-Desrochers and colleagues (2011) reports that some people mention having contracted, on the Internet, computer viruses that affected the functioning of their computer. Dagenais and colleagues (2012) add that several people with disabilities do not have the knowledge and know-how to solve the technical difficulties encountered, thus illustrating the interdependence of technical skills and cognitive functions.

Moreover, the use of technological devices requires periodic solving of technical issues, such as connecting to public or private networks, installing new peripherals, updating applications, Internet searching or devices and repairing software failures (Perriault, 2006 ; Zisimopoulos, Sigafoos, \& Koutromanos, 2011). These basic actions can quickly become complex for people with ID. Consequently, a person who does not have the necessary technical skills will have to turn to other users or to technical-assistance Internet sites.

The environment can play a determining role in providing technical support. The literature indicates that prevention of technical failures is predominant. Therefore, configuring device security, securing the wireless network, installing an antivirus program, setting up the firewall as well as updating the operating system and software are all concrete actions that must be performed (Government of Canada, 2015; HabiloMédias, 2015). However, people with ID need guidance with these processes, which are often cognitively complex (Dagenais et al., 2012). There are currently some sites that provide guidance regarding digital technologies (e.g., Habilomedia.ca addresses several themes, including the risks associated with cybersecurity and what to do to protect oneself). Unfortunately, though, they are not adapted to the cognitive limits of people with ID. In sum, although acquiring technical skills is an important step in promoting access to digital technologies, few concrete actions intended specifically for people with ID have been performed to date.

Dimension relating to social codes and conventions. Access to and participation in the digital society require an understanding of new social interaction rules and conventions. Indeed, there are specific ways to behave or present oneself in this new universe populated with countless individuals and contents that are more or less trustworthy. In fact, prudence is in order with respect to certain forms of personal or promotional solicitation. A good understanding of these codes requires conceptual adaptive abilities, such as abstraction, reasoning and social skills (Chevalier \& Tricot, 2008; Dagenais et al., 2012). People who do not understand these rules could expose themselves to new forms of victimization or exclusion, such as sexual solicitation online, identity theft, impulse buying, harassment, and exposure to unwanted content (Government of Canada, 2015; Holtfreter, Reisig, Pratt, \& Holtfreter, 2015). They may even go as far as jeopardizing their health and safety, for example, by accepting to meet and have unsafe sex with strangers found on the Web (Normand \& Sallafranque St-Louis, 2015; Sallafranque St-Louis, 2015). 
The credulity, tendency to agree, desire to please and impulsivity typical of many people with ID puts them at risk of phishing and fraud (Holtfreter et al., 2015; Wehmeyer, Abery, Mithaug, \& Stancliffe, 2003). Furthermore, it seems that these people have a tendency to immediately accept offers made through pop-up windows on the Internet (Lussier-Desrochers et al., 2011).

When it comes to potential solutions from the environment, few recommendations have been tested, but several have been suggested, including educational programs and individualized support (Dowdell, Burgess, \& Flores, 2011; Holmes \& O'Loughlin, 2014; Raghavendra et al., 2013). Also suggested are computerized, policybased or legal solutions designed to increase data and user security (Charlotte, 2010). For example, Facebook has changed one of its default settings that used to automatically make certain posts public. It is also interesting to note that dating sites now do background checks (e.g., criminal records) on their members. Additionally, in 2011, to promote safe use of social media sites, Autism Speaks issued ten recommendations for adolescents and young adults with autism spectrum disorders (ASD), which are also relevant for people with ID. Notably, they include warnings about sharing personal data (home address, phone number, bank account number, photos), controlling shared information (private groups, open-access Web sites) and meeting with virtual friends in person (meeting in public locations, informing people in their circle, being accompanied).

\section{Model of the Dimensions Relating to Digital Inclusion of People With ID}

In a previous paper, our team proposed a model in the shape of an accessibility pyramid that illustrated the issues relating to digital inclusion (Lussier-Desrochers, Normand et al., 2016). The preliminary presentation of this model at several conferences for caseworkers and researchers triggered various reactions. Caseworkers found that this pyramid-shaped representation provided a simple way to understand and define the dimensions of digital accessibility. Several suggestions were made to improve this first model, including: (a) present the dimensions in a more flexible manner by avoiding a multi-level progression; (b) attribute equal weight to the various dimensions and avoid a presentation mode suggesting that some dimensions are more important; (c) illustrate the dynamic links between the various dimensions; (d) distinguish personal and systemic (environmental) issues; and (e) favour a simple and easy-to-understand presentation.

The results of the review presented here attempt to provide an enhanced model that responds to these proposed improvements. In fact, they are the product of a reflection and numerous debates by the authors. Further to this analysis, our team rejected the idea of a linear-level pyramid model. We felt that a better graphical representation of the digital access dimensions described here and of their interactions was desirable.

These reflections and principles led us to propose a model in the shape of a gear, which is presented in Figure 1.

The centre gear (hub) represents the personal and environmental resources that generate a movement of dynamic interaction with the five peripheral gears, which represent the requirements of the digital world: (a) sensorimotor, (b) cognitive, (c) technical, (d) access to technological devices and (e) codes and conventions. The arrow, for its part, encircles all these dimensions and illustrates that the continuous, dynamic motion is conducive to a person's participation in the path towards digital inclusion. The first advantage of this model is that the hub includes the individual's personal resources and the systemic resources found in his or her environment, which influence the motion of each peripheral gear. These two factors complement each other to ensure the proper operation of the gear system. Some people will be able to attenuate the obstacles to accessibility with individual resources, such as good dexterity or good visual memory. They will then not need to turn to external resources to overcome potential obstacles to manipulating devices or certain Internet browsing components. Conversely, personal factors-such as restricted sensorimotor skills-could limit the use of a computer mouse for others. Resources available in the person's environment could then be helpful. For example, the purchase of an alternative mouse or of a touch screen would help achieve a higher level of accessibility and, potentially, greater digital participation and inclusion. Consequently, as shown by the review, digital inclusion of people with ID is a dynamic process that draws on personal resources and systemic resources from the environment. For instance, the person's cognitive and sensorimotor abilities may be confronted with complex interfaces or unsuitable peripherals, like stones in the gears, that will prevent the person from meeting the requirements of and participating in the digital society. 

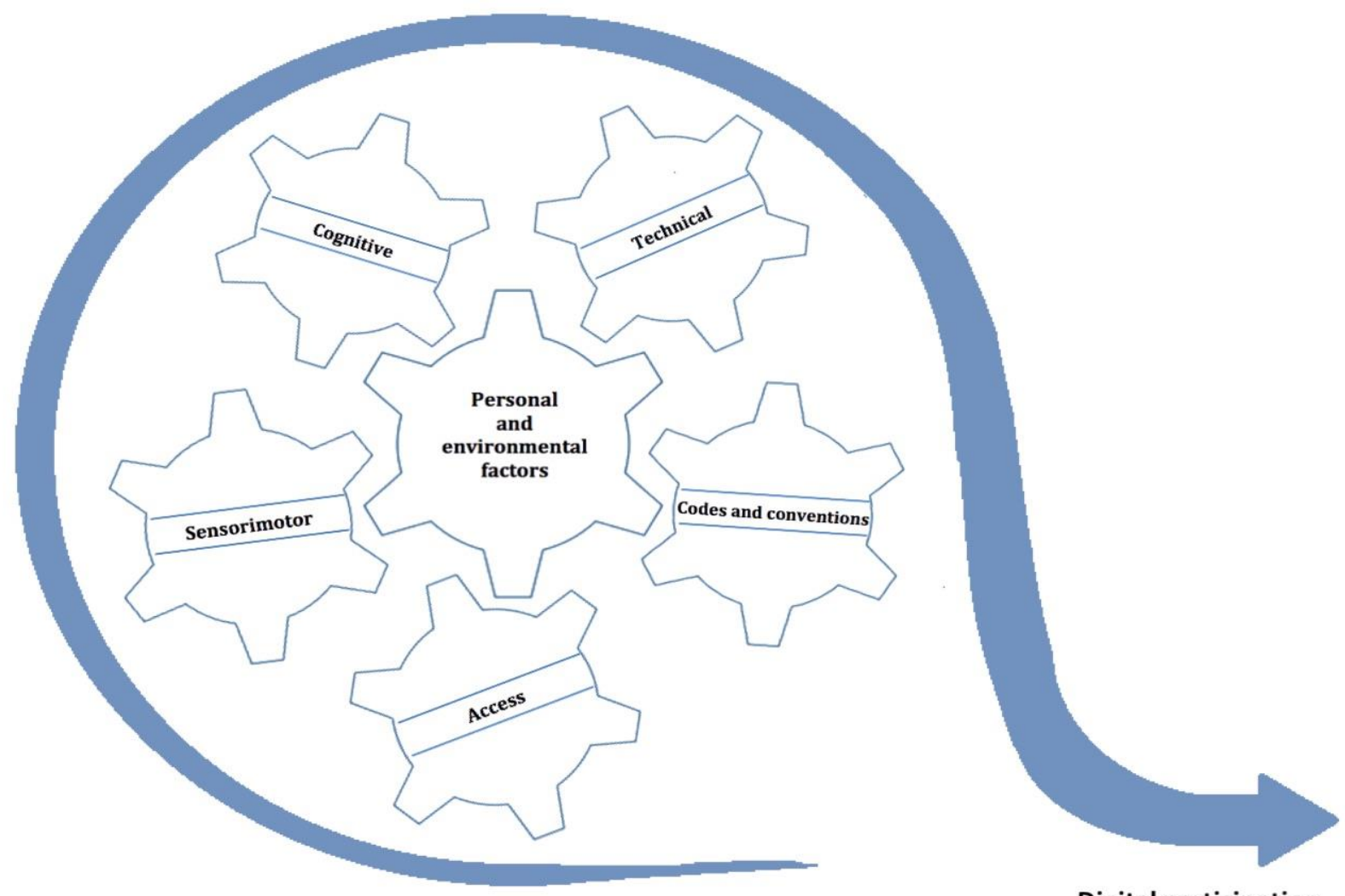

Digital participation

Figure 1. Model of the dynamic links between the digital inclusion dimensions for people with ID.

Basically, this hub, which consists of the person's resources and those from his or her environment influences the opportunities offered to the person to meet the five main requirements of the digital society (the five dimensions documented in the review). A person with good capacities and appropriate environmental support will find it easier to generate an activity on peripheral components and thus advance along the path to digital participation. Conversely, a person facing several obstacles of the digital environment will have difficulty making the gears move along the path to social participation. The hub will thus need to exert greater force, drawing further from the personal or environmental resources, to meet the requirements of the digital society, and overcome the obstacles that may block its path.

This gear model illustrates the efforts required to ensure digital access. The proper operation of the gear system depends on the complementarity of the five dimensions. Nonetheless, this operation will encounter the obstacles identified in the literature. The synergy between individual resources and support from the environment at the centre of the five dimensions must be powerful enough to literally overcome the obstacleslike stones in its path-to participation in the digital world.

\section{Discussion and Conclusion}

The objective of this article was to present the dimensions to consider in order to bridge the digital inclusion gap for people with ID. Based on a literature review, the paper also illustrates how the dimensions interact with one another. This model was intended as a first step in better understanding the issues associated with social participation in the digital society. Although this process is relevant, it has some limits. First, in terms of method, the literature review included only English- and French-language scientific papers. Moreover, research in literature has focused almost exclusively on documentation produced in North America and the generalization of the model is not possible. Also, the concepts and keywords used in the databases are narrow and historical terms may have fallen out of favour. 
It is possible that initiatives to promote digital inclusion exist in other countries and that the results were published in other languages. Moreover, the complementary Google search targeted only Québec initiatives. In the future, it would be relevant to examine international initiatives when performing this step, to obtain a more complete portrait. In brief, the model proposed is limited to the authors' social context and thus limits the possibilities of generalization. Nonetheless, the elements identified in the literature review cover a broader range and help offset this shortcoming to some extent. On the other hand, the article didn't fully covered gatekeeping and the interaction between risk perceptions and permissions for access. Therefore it represents another limit of our work.

Meanwhile, the model itself is derived simply from the authors' reflections based on their experiences and their consultation of the elements found in the literature. In future studies, it would be interesting to compare this model with other authors' proposed models. For example, Beukelman and Mirenda (2013) propose an evaluation model in the field of communication aids that include several of the components identified in our model and overlap the factors identified in the review by Chadwick et al. (2013). They also present it in the form of a decision tree. While these authors focus only on communication assistance, the model proposed could motivate the continuation of the reflection by research teams interested in the subject.

Still regarding the method, it would be interesting to conduct a study of an in situ application of the model with people with ID. In this type of study, the model could be compared with the people's reality and a social validation could be performed. Quantitative studies involving correlational and factorial designs should also be used to examine the validity and fidelity of the model proposed. The weight of the various factors could then be determined. Indeed, our review showed that certain dimensions are extensively documented while others are just emerging. Studies of this nature would thus enable us to find out whether the low level of documentation of a component is linked to its emerging nature or rather to its relative weight compared with other variables.

Finally, the new model does not include the ethical or psychosocial issues identified in the previous pyramid model. This omission is intentional; ethical issues are a cross-sectional theme and psychosocial issues appear to result from a digital inclusion process. This does not mean, however, that these elements should be dismissed. On the contrary, ethical issues related to the use of technologies with these people could constitute, on their own, the content of a scientific publication. In short, our team stresses the importance of considering this dimension at every step of the way, when technologies are used with people with ID. Meanwhile, psychosocial issues has been considered extensively in the review by Chadwick et al. (2013) and in the review by Caton and Chapman (2016). It is recommended that this area of research be actively developed over the next few years.

Nonetheless, this first model helps to further the reflection on the subject. We hope that it will contribute to the advancement of knowledge in this sector and that collective actions will ultimately reduce the risks of exclusion, increase accessibility and promote social participation and inclusion of these people in the digital world.

\section{References}

\#CTI. (2016, June). Charte pour des technologies inclusives [Convention for inclusive technologies]. Contribution from the 15th meeting of the Institut universitaire en déficience intellectuelle et en trouble du spectre de l'autisme of Centre de partage d'expertise en intervention technoclinique and the Institut universitaire en déficience intellectuelle et en trouble du spectre de l'autisme, in connection with the CIUSSS de la Mauricie-etdu-Centre-du-Québec, Trois-Rivières, Québec.

Abilities Expo. (2015). Assistive technology showcase: Interact with tomorrow's technology today [Web log post]. Retrieved from http://www.abilities.com/houston/pavilions_assistive.html

Allard, L. (2007). Émergence des cultures expressives, d'internet au mobile [Emergence of expressive cultures, from internet to mobile technologies]. Médiamorphoses, 21, 19-25.

Allen, K. D., Vatland, C., Bowen, S. L., \& Burke, R. V. (2015). An evaluation of parent-produced video self-modeling to improve independence in an adolescent with intellectual developmental disorder and an autism spectrum disorder: A controlled case study. Behavior Modification, 39, 542-556.

http://dx.doi.org/10.1177/0145445515583247 
American Association on Intellectual and Developmental Disabilities (AAIDD). (2010). Definition, Classification, and Systems of Supports (11th ed.). Washington, DC: Author.

American Association on Intellectual and Developmental Disabilities (AAIDD). (2016, June 23). Community living and participation for people with intellectual and developmental disabilities [Newsgroup]. Retrieved from http://aaidd.org/news-policy/policy/position-statements/community-living-and-participation\#.V4ZZIlddKQs

Association québécoise des troubles d'apprentissage (AQETA). (2016). Mesure 30810 du MELS [Newsgroup]. Retrieved from http://www.aqetaoutaouais.qc.ca/WP/?page_id=787

Attour, A., \& Longhi, C. (2009). Fracture numérique: Le chaînon manquant [Digital devide: the missing link]. Les Cahiers du numérique, 5(1), 119-146.

Autism Speaks. (2011). Transition tool kit: A guide to assist families on the journey from adolescence to adulthood [Newsgroup]. Retrieved from https://www.autismspeaks.org/family-services/tool-kits/transition-tool-kit

Ayres, K. M., Mechling, L., \& Sansosti, F. J. (2013). The use of mobile technologies to assist with life skills/independence of students with moderate/severe intellectual disability and/or autism spectrum disorders: Considerations for the future of school psychology. Psychology in the Schools, 50, 259-271.

http://dx.doi.org/10.1002/pits.21673

Batey, G., \& Waine, H. (2015). Safe Internet access for service users. Learning Disability Practice, 18(3), 16-20. http://dx.doi.org/10.7748/ldp.18.3.16.e1613

Beukelman, D., \& Mirenda, P. (2013). Augmentative and alternative communication: Supporting children and adults with complex communication needs (4th ed.). Baltimore, MD: Paul H. Brookes.

Blanck, P. (2014). The struggle for web eQuality by persons with cognitive disabilities. Behavioral Sciences and the Law, 32, 4-32. http://dx.doi.org/10.1002/bsl.2101

Brangier, E., Hammes-Adelé, S., \& Bastien, J.-M. C. (2010). Analyse critique des approches de l'acceptation des technologies: De l'utilisabilité à la symbiose humain-technologie-organisation [Critical analysis of approaches to technology acceptance: From usability to human symbiosis-technology-organization]. Revue européenne de psychologie appliquée, 60, 129-146. http://dx.doi.org/10.1016/j.erap.2009.11.002

Buijs, P. C. M., Boot, E., Shugar, A., Fung, W. L. A. et Bassett, A. S. (2016). Internet safety issues for adolescents and adults with intellectual disabilities. Journal Of Applied Research In Intellectual Disabilities.

http://dx.doi.org/10.1111/jar.12250

Bunning, K., Trapp, E., Seymour, K., Fowler, M., \& Rollett, B. (2010). Survey of the linguistic accessibility of websites designed for people with intellectual disability. Journal of Applied Linguistics \& Professional Practice, 7, 297-316. http://dx.doi.org/10.1558/japl.v7i3.297

Burckley, E., Tincani, M., \& Guld Fisher, A. (2015). An iPad ${ }^{\mathrm{TM}}$-based picture and video activity schedule increases community shopping skills of a young adult with autism spectrum disorder and intellectual disability.

Developmental Neurorehabilitation, 18, 131-136. http://dx.doi.org/10.3109/17518423.2014.945045

Canadian Association for Community Living. (2013). Équité et sécurité du revenu pour les canadiens ayant une déficience intellectuelle et leur famille [Equity and income security for Canadians with intellectual disability and their family]. Retrieved from

http://www.parl.gc.ca/Content/HOC/Committee/411/FINA/WebDoc/WD6079428/411_FINA_IIC_Briefs\%5CCanadia nAssociationforCommunityLivingF8629862.pdf

Carey, A. C., Friedman, M. G., \& Bryen, D. N. (2005). Use of electronic technologies by people with intellectual disabilities. Mental Retardation, 43, 322-333. http://dx.doi.org/10.1352/0047-6765(2005)43[322:UOETBP]2.0.CO;2

Carmeli, E., Bar-Yossef, T., Ariav, C., Levy, R., \& Liebermann, D. G. (2008). Perceptual-motor coordination in persons with mild intellectual disability. Disability and Rehabilitation, 30, 323-329.

Caton, S., \& Chapman, M. (2016). The use of social media and people with intellectual disability: A systematic review and thematic analysis. Journal of Intellectual \& Developmental Disability, 41, 125-139. 
Centre facilitant la recherche et l'innovation dans les organisations (CEFRIO). (2015). Le commerce électronique au Québec: Croissances des achats en lignes sur mobile [E-commerce in Quebec: Growth in mobile phone purchases]. NETendances 2014, 5(9), 1-15. Retrieved from http://www.cefrio.qc.ca/media/uploader/FasciculeCommercelectronique_Versionfinale.pdf

Chadwick, D., Quinn, S., \& Fullwood, C. (2016). Perceptions of risks and benefits of Internet access and use by people with intellectual disabilities. British Journal of Learning Disabilities, 45, 21-31.

Chadwick, D., Wesson, C., \& Fullwood, C. (2013). Internet access by people with intellectual disabilities: Inequalities and opportunities. Future Internet, 5, 376-397. http://dx.doi.org/10.3390/fi5030376

Charlotte, C. (2010). Internet safety survey: Who will protect the children? Berkeley Technology Law Journal, 25, 501-527. http://dx.doi.org/10.15779/Z38HQ3D

Chen, H.-Y. (2010). Online reading comprehension strategies among fifth- and sixth-grade general and special education students. Education Research and Perspectives, 37, 79-109.

Chevalier, A., \& Tricot, A. (2008). Ergonomie des documents électroniques [Ergonomics of electronic documents]. Paris, France: Presses universitaires de France.

Cleaver, S., Ouellette-Kuntz, H., \& Hunter, D. (2009). The prevalence and severity of physical mobility limitations in older adults with intellectual disabilities. Journal of Applied Research in Intellectual Disabilities, 22, 477-486. http://dx.doi.org/10.1111/j.1468-3148.2009.00499

Coleman Institute for Cognitive Disabilities. (2013). The rights of people with cognitive disabilities to technology and information access [Newsgroup]. Retrieved from http://www.colemaninstitute.org/declaration-text

Compiègne, I. (2011). La société numérique en question(s) [The digital society in questions]. Auxerre, France: Sciences Humaines Éditions.

Crow, K. (2008). Four types of disabilities: Their impact on online learning. TechTrends, 52(1), 51-55.

Dagenais, D., Poirier, K., \& Quidot, S. (2012). L'inclusion numérique telle qu'expérimentée par les citoyens handicapés au Québec (INTECH Québec: Raconter l'expérience et comprendre les pratiques: l'inclusion numérique des personnes handicapées au Québec [Digital inclusion as experienced by disabled citizens in Quebec (INTECH Québec: Telling the experience and understanding the practices: digital inclusion of people with disabilities in Quebec]. Retrieved from http://www.communautique.qc.ca/media/INTECH.version2.PDF.pdf

Danial-Saad, A., Weiss, P. L. T., \& Schreuer, N. (2012). Assessment of computer task performance (ACTP) of children and youth with intellectual and developmental disability. Disability and Rehabilitation: Assistive Technology, 7, 450-458. http://dx.doi.org/10.3109/17483107.2011.650780

Danielsson, H., Henry, L., Messer, D., \& Rönnberg, J. (2012). Strengths and weaknesses in executive functioning in children with intellectual disability. Research in Developmental Disabilities, 33, 600-607.

http://dx.doi.org/10.1016/j.ridd.2011.11.004

Davies, D. K., Stock, S. E., King, L. R., Brown, R. B., Wehmeyer, M. L., \& Shogren, K. A. (2015). An interface to support independent use of Facebook by people with intellectual disability. Intellectual \& Developmental Disabilities, 53, 30-41. http://dx.doi.org/10.1352/1934-9556-53.1.30

Davies, D. K., Stock, S. E., \& Wehmeyer, M. L. (2002). Enhancing independent time-management skills of individuals with mental retardation using a palmtop personal computer. Mental Retardation, 40, 358-365. http://dx.doi.org/10.1352/0047-6765(2002)040<0358:EITMSO>2.0.CO;2

Dowdell, E. B., Burgess, A. W., \& Flores, J. R. (2011). Original research: Online social networking patterns among adolescents, young adults, and sexual offenders. The American Journal of Nursing, 111(7), 28-36.

http://dx.doi.org/10.1097/01.NAJ.0000399310.83160.73

Dube, W. V., \& Wilkinson. K. M. (2014). The potential influence of stimulus overselectivity in AAC: Information from eye tracking and behavioral studies of attention with individuals with intellectual disabilities. Augmentative and Alternative Communication, 30, 172-185. http://dx.doi.org/10.3109/07434618.2014.904924 
Eveno, E. (1998). Parthenay, modèle français et européen de ville numérisée [Parthenay, French and European model of digital city]. In A. Lefebre \& G. Tremblay (Eds.), Autoroutes de l'information et dynamiques territoriales (pp. 131-152). Sainte-Foy, Québec: Presses de l'Université du Québec.

Fédération québécoise des Centres de Réadaptation en Déficience intellectuelle (FQCRDITED). (2013). La participation sociale des personnes présentant une déficience intellectuelle ou un trouble envahissant $d u$ développement : du discours à une action concertée (Research Report) [Social participation of people with intellectual disability or autism spectrum disorders: From discourse to action]. Retrieved from http://internet.crditedmtl.ca/wp-content/uploads/2014/02/Participation-sociale.pdf

Fougeyrollas, P., Cloutier, R., Bergeron, H., Côté, J., \& St-Michel, G. (1998). Classification québécoise: Processus de production du handicap [Quebec Disability Creation Process]. Québec, Québec: Réseau international sur le processus de production du handicap.

Government of Canada. (2015). Cyber Security Risks. Retrieved from http://www.getcybersafe.gc.ca/cnt/rsks/index-en.aspx

Grace, E., Raghavendra, P., Newman, L., Wood, D., \& Connell, T. (2014). Learning to use the Internet online social media: What is the effectiveness of home-based intervention for youth with complex communication needs? Child Language Teaching \& Therapy, 30, 141-157. http://dx.doi.org/10.1177/0265659013518565

HabiloMédias. (2015). Cybersécurité [Newsgroup] [Cybersecurity]. Retrieved from http://habilomedias.ca/littératie-numérique-et-éducation-aux-médias/enjeux-numériques/cybersécurité

Hall, V., Conboy-Hill, S., \& Taylor, D. (2011). Using virtual reality to provide health care information to people with intellectual disabilities: Acceptability, usability, and potential utility. Journal of Medical Internet Research, 13, e91. http://dx.doi.org/10.2196/jmir.1917

Harrysson, B., Svensk, A., \& Johansson, G. I. (2004). How people with developmental disabilities navigate the Internet. British Journal of Special Education, 31, 138-142. http://dx.doi.org/10.1111/j.0952-3383.2004.00344

Holmes, K. M., \& O'Loughlin, N. (2014). The experiences of people with learning disabilities on social networking sites. British Journal of Learning Disabilities, 42, 1-5. http://dx.doi.org/10.1111/bld.12001

Holtfreter, K., Reisig, M. D., Pratt, T. C., \& Holtfreter, R. E. (2015). Risky remote purchasing and identity theft victimization among older Internet users. Psychology, Crime \& Law, 21, 681-698.

http://dx.doi.org/10.1080/1068316X.2015.1028545

Hoppestad, B. S. (2013). Current perspective regarding adults with intellectual and developmental disabilities accessing computer technology. Disability and Rehabilitation: Assistive Technology, 8, 190-194.

http://dx.doi.org/10.3109/17483107.2012.723239

Institut de la statistique du Québec. (2013, April). Les technologies de l'information et des communications dans les ménages québécois [Information and communication technologies in Quebec households]. Retrieved from http://www.stat.gouv.qc.ca/statistiques/science-technologie-innovation/bulletins/sti-bref-201304.pdf

Jenkins. H. (2006). Convergence culture. How old and new media collide. New-York, NY: New York University Press.

Karreman, J., van der Geest, T., \& Buursink, E. (2007). Accessible website content guidelines for users with intellectual disabilities. Journal of Applied Research in Intellectual Disabilities, 20, 510-518.

http://dx.doi.org/10.1111/j.1468-3148.2006.00353.x

Kennedy, H., Evans, S., \& Thomas, S. (2011). Can the web be made accessible for people with intellectual disabilities? Information Society, 27(1), 29-39. http://dx.doi.org/10.1080/01972243.2011.534365

Lachapelle, Y., Lussier-Desrochers, D., Caouette, M., \& Therrien-Bélec, M. (2011). Évaluation des impacts d'une technologie mobile d'assistance à la réalisation de tâches sur l'autodétermination des personnes présentant une déficience intellectuelle [Research Report] [Assessing the impacts of mobile assistive technology on people with intellectual disabilities' self-determination]. Trois-Rivières, Québec: Chaire de recherche sur les technologies de soutien à l'autodétermination. 
Lachapelle, Y., Lussier-Desrochers, D., \& Pigot, H. (2007). Des TIC en soutien à l'autodétermination des personnes présentant une déficience intellectuelle [ICTs in support of self-determination of people with intellectual disabilities]. Revue québécoise de psychologie, 28, 111-123.

Lachapelle, Y., \& Therrien-Bélec, M. (2013). Technologies de soutien à l'autodétermination et participation sociale: De la théorie à la pratique! [Technologies to support self-determination and social participation: From theory to practice!] Revue développement humain, handicap et changement social, 21(1), 7-15.

Lachapelle, Y., \& Wehmeyer, M. L. (2003). L'autodétermination [Self-determination]. In M. J. Tassé \& D. Morin (Eds.), La déficience intellectuelle (pp. 203-214). Boucherville, Québec: Gaëtan Morin.

Langevin, J., Rocque, S., Ngongang, I., \& Chalghoumi, H. (2012). Balises et processus d'adaptation au regard de limitations cognitives [Adaptation processes with regard to cognitive limitations]. In J. Viens, J. Langevin, M. SaintPierre, \& S. Rocque (Eds.), Pour des technologies accessibles aux élèves handicapés ou en difficulté d'apprentissage ou d'adaptation (pp. 193-219). Montréal, Québec: Éditions Nouvelles.

Licoppe, C. (2009). L'évolution des cultures numériques: De la mutation du lien social à l'organisation du travail [Evolution of digital cultures: From the mutation of the social bond to the organization of work]. Limoges, France: Fyp.

Light, J., \& Mcnaughton, D. (2014). From basic to applied research to improve outcomes for individuals who require augmentative and alternative communication: Potential contributions of eye tracking research methods. Augmentative and Alternative Communication, 30, 99-105. http://dx.doi.org/10.3109/07434618.2014.906498

Löfgren-Mårtenson, L., Sorbring, E., \& Molin, M. (2015). "T@ngled up in blue": Views of parents and professionals on Internet use for sexual purposes among young people with intellectual disabilities. Sexuality \& Disability, 33 , 533-544. http://dx.doi.org/10.1007/s11195-015-9415-7

Lussier-Desrochers, D., Caouette, M., \& Godin-Tremblay, V. (2015). Étude sur les perceptions des acteurs-clés en lien avec l'implantation de l'innovation technologique au CRDITED de la Montérégie-Est (Research Report) [Study on the perceptions of stakeholder in relation to the implementation of technological innovation at the CRDITED in the Montérégie-Est region]. Trois-Rivières, Québec: Université du Québec à Trois-Rivières.

Lussier-Desrochers, D., Caouette, M., \& Godin-Tremblay, V. (2016). Démarche exploratoire sur les tablettes numériques en soutien à la suppléance à la communication orale pour les personnes présentant une déficience intellectuelle (DI) ou un trouble du spectre de l'autisme (TSA) (Research Report) [Exploratory approach to digital tablets in support of oral communication for persons with intellectual disabilities (ID) or autism spectrum disorder (ASD)]. Trois-Rivières, Québec: Centre de partage d'expertise en intervention technoclinique.

Lussier-Desrochers, D., Dupont, M.-È., Lachapelle, Y., \& Leblanc, T. (2011). Étude exploratoire sur l'utilisation de I'Internet par les personnes présentant une déficience intellectuelle [Exploratory study on the use of the Internet by people with intellectual disabilities]. Revue Francophone de la Déficience Intellectuelle, 22, 41-50.

Lussier-Desrochers, D., Mahalache, I., Caouette, M., Ruel, J., Godin-Tremblay, V., \& Dallaire, S. (2014). Étude sur les perceptions des acteurs-clés en lien avec l'implantation de l'innovation technologique au Pavillon du Parc [Research Report] [Study on the perceptions of key players in relation to the implementation of technological innovation in Outaouais region]. Trois-Rivières, Québec: Université du Québec à Trois-Rivières.

Lussier-Desrochers, D., L. Normand, C., Fecteau, S., Roux, J., Godin-Tremblay, V., Dupont, M.-È., . . PépinBeauchesne, L. (2016). Modélisation soutenant l'inclusion numérique des personnes présentant une DI ou un TSA [Supporting the digital inclusion of people with ID or ASD: A Model]. Revue Francophone de la Déficience Intellectuelle, 27, 5-24.

McClimens, A., \& Gordon, F. (2009). People with intellectual disabilities as bloggers: What's social capital got to do with it anyway? Journal of Intellectual Disabilities, 13, 19-30. http://dx.doi.org/10.1177/1744629509104486

Mechling, L. C., \& Seid, N. H. (2011). Use of a hand-held personal digital assistant (PDA) to self-prompt pedestrian travel by young adults with moderate intellectual disabilities. Education and Training in Autism and Developemental Disabilities, 46, 220-237. 
Michel, G., Masson, R., \& Sperandio, J.-C. (2006) Internet est-il accessible aux personnes ayant des incapacités? [ls the Internet accessible to people with disabilities?] Développement Humain, Handicap rt Changement Social, 15(1).

Miles, M. B., \& Huberman, M. A. (2003). Analyse des données qualitatives (2nd ed.) [Analysis of qualitative data]. Paris, France: De Boeck.

Moisey, S., \& van de Keere, R. (2007). Inclusion and the Internet: Teaching adults with developmental disabilities to use information and communication technology. Developmental Disabilities Bulletin, 35, 72-102.

Molin, M., Sorbring, E., \& Löfgren-Mårtenson, L. (2015). Teachers' and parents' views on the Internet and social media usage by pupils with intellectual disabilities. Journal of Intellectual Disabilities, 19, 22-33.

http://dx.doi.org/10.1177/1744629514563558

Morphy, E. (2010, April 2). What your iPad will really cost you - Hope you're sitting down. TechNewsWorld. Retrieved from http://www.technewsworld.com/story/69679.html

Näslund, R., \& Gardelli, Å. (2013). "I know, I can, I will try": Youths and adults with intellectual disabilities in Sweden using information and communication technology in their everyday life. Disability \& Society, 28, 28-40. http://dx.doi.org/10.1080/09687599.2012.695528

Newman, R. C. (2009). Computer security: Protecting digital resources. Sudbury, MA: Jones \& Bartlett.

Normand, C., Rodier, S., Lussier-Desrochers, D., \& Giguère, L. (submitted). Peut-on favoriser l'inclusion sociale des jeunes par l'utilisation d'Internet? [Can the social inclusion of young people be promoted through the use of the Internet?] Revue Francophone de la Déficience Intellectuelle.

Normand, C. L., \& Sallafranque St-Louis, F. (2015). Cybervictimization of young people with an intellectual or developmental disability: Risks specific to social solicitation. Journal of Applied Research in Intellectual Disabilities, 29, 99-110. http://dx.doi.org/10.1111/jar.12163

Normand, C. L., \& Sallafranque St-Louis, F. (2016, June). Risks and benefits of internet use by people with neurodevelopmental disorders. Poster session presented at the 21st Annual CyberPsychology, CyberTherapy and Social Networking Conference, Dublin, Ireland.

Office des personnes handicapées du Québec (OPHQ). (2009). À part entière: Pour un véritable exercice du droit à l'égalité [Research Report] [Full-fledged: Towards a real exercise of the right to equality]. Retrieved from https://www.ophq.gouv.qc.ca/fileadmin/documents/Politique_a_part_entiere_Acc.pdf

Office des personnes handicapées du Québec (OPHQ). (2011). Guide des programmes d'aide pour les personnes handicapées et leur famille [Research Report] [Guide to people with disabilities and family assistance programs]. Retrieved from https://www.ophq.gouv.qc.ca/fileadmin/documents/Guide_des_Programmes_complet.pdf

Office des personnes handicapées du Québec (OPHQ). (2013). Auditions publiques sur l'augmentation des prestations d'aide sociale pour les personnes handicapées [Public auditions on increasing welfare benefits for people with disabilities]. Retrieved from

https://www.ophq.gouv.qc.ca/fileadmin/centre_documentaire/Memoires_et_avis/Memoire_OPHQ_soutien_reven u_Acc.pdf

Organisation for Economic Co-operation and Development (OECD). (2004). L'administration électronique, un impératif [E-government, an imperative]. Retrieved from http://www.keepeek.com/Digital-AssetManagement/oecd/governance/l-administration-electronique-un-imperatif_9789264101203-fr\#.V9LbmZjhAdU

Palmer, S. B., Wehmeyer, M. L., Davies, D., \& Stock, S. (2012). Family members' reports of the technology use of family members with intellectual and developmental disabilities. Journal of Intellectual Disability Research, 56, 402414. http://dx.doi.org/10.1111/j.1365-2788.2011.01489

Parsons, S., Daniels, H., Porter, J., \& Robertson, C. (2008). Resources, staff beliefs and organizational culture: Factors in the use of information and communication technology for adults with intellectual disabilities. Journal of Applied Research in Intellectual Disabilities, 21, 19-33. http://dx.doi.org/10.1111/j.1468-3148.2007.00361 
Perkins, E. A., \& LaMartin, K. M. (2012). The Internet as social support for older carers of adults with intellectual disabilities. Journal of Policy \& Practice in Intellectual Disabilities, 9, 53-62. http://dx.doi.org/10.1111/j.17411130.2012 .00330

Perriault, J. (2006). La norme comme instrument d'accès au savoir en ligne [The standard as an instrument of access to knowledge online]. Hermès, La Revue, 45, 77-87.

President's Committee for People with Intellectual Disabilities (PCPID). (2015). Leveling the playing field: Improving technology access and design for people with intellectual disabilities. Retrieved from

http://www.acl.gov/programs/aidd/Programs/PCPID/docs/PCPID-2015-Report-to-President.pdf

Principled Technologies. (2013, January). Tablets in the enterprise: Comparing the total cost of ownership. $A$ Principled Technologies white paper. Retrieved from

http://mobilecomputing.crn.com/img/Tablet_TCO_PT_Final_Feb_2013.pdf

Projet ministériel d'aide technique à la communication (PMATCOM). (2015). Catégories d'aides techniques [Newsgroup] [Technical aids categories]. Retrieved from http://www.pmatcom.qc.ca/categorie-aidestechniques.html

Raghavendra, P., Newman, L., Grace, E., \& Wood, D. (2013). 'I could never do that before': Effectiveness of a tailored Internet support intervention to increase the social participation of youth with disabilities. Child: Care, Health \& Development, 39, 552-561. http://dx.doi.org/10.1111/cch.12048

Reichenberg, M. (2016). Who will present it during the broadcast? A case study of a daily activity centre. Journal of Research in Special Educational Needs, 16, 65-73.

Rivas-Costas, C., Anido-Rifon, L., Fernandez-Iglesias, M. J., Gomez-Carballa, M. A., Valladares-Rodriguez, S., \& Soto-Barreiros, R. (2014). An accessible platform for people with disabilities. International Journal of HumanComputer Interaction, 30, 480-494. http://dx.doi.org/10.1080/10447318.2014.888503

Rocha, T., Bessa, M., Gonçalves, M., Cabral, L., Godinho, F., Peres, E., . . Chalmers, A. (2012). The recognition of web pages' hyperlinks by people with intellectual disabilities: An evaluation study. Journal of Applied Research in Intellectual Disabilities, 25, 542-552. http://dx.doi.org/10.1111/j.1468-3148.2012.00700

Sallafranque St-Louis, F. (2015). L'utilisation d'Internet et la sollicitation sexuelle sur le web auprès des personnes avec une déficience intellectuelle (DI) ou un trouble du spectre de l'autisme. [Doctoral dissertation] [The use of the Internet and sexual solicitation among people with intellectual disabilities (ID) or autism spectrum disorder]. Retrieved from http://di.uqo.ca/818/1/Essai_Francois_SallafranqueSt-Louis_2015.pdf

Seale, J. (2014). The role of supporters in facilitating the use of technologies by adolescents and adults with learning disabilities: A place for positive risk-taking? European Journal of Special Needs Education, 29, 220-236. http://dx.doi.org/10.1080/08856257.2014.906980

Shpigelman, C.-N. (2016, July). Sense of belonging of Facebook users with intellectual disabilities. Paper presented at the Fifth Conference of Alter, European Society for Research on Disability, Stockholm, Sweden.

Shpigelman, C.-N., \& Gill, C. J. (2014). How do adults with intellectual disabilities use Facebook? Disability \& Society, 29, 1601-1616. http://dx.doi.org/10.1080/09687599.2014.966186

Sigafoos, J., O’Reilly, M., Cannella, H., Upadhyaya, L., Edrinsinha, C., Lancioni, G. E., ...Young, D. (2005). Computerpresented video prompting for teaching microwave oven use to three adults with developmental disabilities. Journal of Behavioral Education, 14, 189-201. http://dx.doi.org/10.1007/s10864-005-6297-2

Stephenson, J., \& Limbrick, L. (2015). A review of the use of touch-screen mobile devices by people with developmental disabilities. Journal of Autism and Developmental Disorders, 45, 3777-3791.

http://dx.doi.org/10.1007/s10803-013-1878-8

Stock, S. E., Davies, D. K., Davies, K. R., \& Wehmeyer, M. L. (2006). Evaluation of an application for making palmtop computers accessible to individuals with intellectual disabilities. Journal of Intellectual \& Developmental Disability, 31, 39-46. http://dx.doi.org/10.1080/13668250500488645 
Taber-Doughty, T., Shurr, J., Brewer, J., \& Kubik, S. (2010). Standard care and telecare services: Comparing the effectiveness of two service systems with consumers with intellectual disabilities. Journal of Intellectual Disability Research, 54, 843-859. http://dx.doi.org/10.1111/j.1365-2788.2010.01314

Tanis, E. S., Palmer, S., Wehmeyer, M., Davies, D. K., Stock, S. E., Lobb, K., \& Bishop, B. (2012). Self-report computer-based survey of technology use by people with intellectual and developmental disabilities. Intellectual and Developmental Disabilities, 50, 53-68. http://dx.doi.org/10.1352/1934-9556-50.1.53

Tassé, M. J., \& Morin, D. (2003). La déficience intellectuelle [Intellectual disability]. Montréal, Québec: Gaëtan Morin.

Tricot, A. (2007). Apprentissage et documents numériques [Learning and digital documents]. Paris, France: Berlin.

United Nations. (2006). Final report of the Ad Hoc Committee on a comprehensive and integral international convention on the protection and promotion of the rights and dignity of persons with disabilities. Retrieved from https://documents-dds-ny.un.org/doc/UNDOC/LTD/N06/645/30/pdf/N0664530.pdf?OpenElement

Ville de Trois-Rivières. (2015). Poste Internet - Réseau sans fil [Newsgroup] [Internet - Wireless]. Retrieved from http://citoyen.v3r.net/portail/index.aspx?sect=0\&module=5\&module2=1\&MenulD=1016\&CPage=1

Vodoz, L. (2010, December). Fracture numérique, fracture sociale: Aux frontières de l'intégration et de l'exclusion [Digital divide, social divide: The frontiers of integration and exclusion]. SociologieS. Retrieved from http://sociologies.revues.org/3333

Watkins, A. (2014). Model policy for inclusive ITCs in education for persons with disabilities. Paris, France: UNESCO.

Wehmeyer, M. L., Abery, B. H., Mithaug, D. E., \& Stancliffe, R. J. (2003). Theory in self-determination. Springfield, IL: Charles C. Thomas.

Wehmeyer, M. L., Palmer, S., Smith, S. J., Davies, D., \& Stock, S. (2008). The efficacy of technology use by people with intellectual disability: A single-subject design meta-analysis. Journal of Special Education and Training, 23(3), 13-24.

Wells, M., \& Mitchell, K. J. (2014). Patterns of Internet use and risk of online victimization for youth with and without disabilities. The Journal of Special Education, 48, 204-213. http://dx.doi.org/10.1177/0022466913479141

Williams, P., \& Hennig, C. (2015). Optimising web site designs for people with learning disabilities. Journal of Research in Special Educational Needs, 15(1), 25-36. http://dx.doi.org/10.1111/1471-3802.12034

Williams, P., \& Nicholas, D. (2006). Testing the usability of information technology applications with learners with special educational needs (SEN). Journal of Research in Special Educational Needs, 6(1), 31-41.

http://dx.doi.org/10.1111/j.1471-3802.2006.00057

Wong, A. W. K., Chan, C. C. H., Li-Tsang, C. W. P., \& Lam, C. S. (2009). Competence of people with intellectual disabilities on using human-computer interface. Research in Developmental Disabilities, 30, 107-123.

http://dx.doi.org/10.1016/j.ridd.2008.01.002

World Health Organization (WHO). (2010). Better health, better lives: children and young people with intellectual disabilities and their families. Bucharest, Romania: Author.

Wu, P.-F., Cannella-Malone, H. I., Wheaton, J. E., \& Tullis, C. A. (2016). Using video prompting with different fading procedures to teach daily living skills: A preliminary examination. Focus on Autism and Other Developemental Disabilities, 31, 129-139. http://dx.doi.org/10.1177/1088357614533594

Zisimopoulos, D., Sigafoos, J., \& Koutromanos, G. (2011). Using video prompting and constant time delay to teach an Internet search basic skill to student with intellectual disabilities. Education and Training in Autism and Developmental Disabilities, 46, 238-250. 


\section{Correspondence to:}

Dany Lussier-Desrochers

Psychoéducation

Université du Québec à Trois-Rivières

3351 Boul. des Forges

C.P. 500, Trois-Rivières

Québec

G9A 5 H7

Email: dany.lussier-desrochers@uqtr.ca

\section{About Authors}

Dany Lussier-Desrochers is Professor in Psychoeducation at the University of Quebec in Trois-Rivières (Canada). He's also the director of a Canadian expertise center promoting digital inclusion of people with intellectual disability and autism.

Claude L. Normand is Associate Professor in Psychoeducation and Psychology at the Université du Québec en Outaouais, in Canada. Her research focuses on inclusion and social participation, online and offline, of people with intellectual or developmental disabilities.

Alejandro Romero is a professor at the School of Management at the University of Quebec at Montreal (UQAM). $\mathrm{He}$ is currently a member of the core committee for revising the Project Management Book of Knowledge (PMBOK) of Project Management Institute (PMI). His principal research interests are related to technology management, project management, digital transformation and Smart city.

Yves Lachapelle is a full professor of Psychoeducation at the Université du Québec à Trois-Rivières in Canada. Dr. Lachapelle specializes in research on social inclusion of people with intellectual disability and focuses on areas of self-determination and social participation through the use of assistive technologies. He chairs the Quebec Chapter of the American Association on Intellectual and Developmental Disabilities and is a Fellow of the national AAIDD.

Valérie Godin-Tremblay is a Ph.D. candidate in psychoeducation at the University of Quebec in Trois-Rivières (Canada). She's currently coordinating the activities of a Canadian expertise center promoting digital inclusion of people with intellectual disability and autism.

Marie-Ève Dupont is a Ph.D. candidate in psychoeducation at the University of Quebec in Trois-Rivières (Canada). She's currently coordinating the activities of the a Canadian expertise center promoting digital inclusion of people with intellectual disability and autism.

Jeannie Roux is working at University Institute in Intellectual Disability and Autism Spectrum Disorder. She's also assisting Quebec rehabilitation centers' in the implementation of technologies aimed at people with intellectual disability and autism spectrum disorder.

Laurence Pépin-Beauchesne is a research assistant at a Canadian expertise center promoting digital inclusion of people with intellectual disability and autism.

Pascale Bilodeau is a research assistant at a Canadian expertise center promoting digital inclusion of people with intellectual disability and autism.

Editorial record: First submission received on September 9, 2016. Revision received on January 17, 2017. Accepted for publication on May 5, 2017. The article is part of Special Issue "Internet use and disability - Risks, opportunities and challenges" guest edited by Emma Sorbring and Martin Molin. 